\title{
The relationship between body composition and foot posture index in Special Olympics athletes
}

\author{
MARTA GIMUNOVÁ*, HANA VÁLKOVÁ, TOMÁŠ KALINA, TOMÁŠ VODIČKA \\ Faculty of Sports Studies, Masaryk University, Brno, Czech Republic.
}

\begin{abstract}
Purpose: In Special Olympics, athletes' foot deformities, abnormal postural patterns and overweight and obesity were observed to be more common than in the general population. Therefore, the purpose of this study was to analyze the relationship between body composition and foot posture index. Additionally, the effect of gender and other factors on the body composition and foot posture index in athletes with intellectual disability (ID) were analyzed. Methods: 131 athletes with ID participated in this study: 36 table tennis players, 66 cross country skiers and 29 downhill skiers. Their body composition was assessed using the bioimpedance analysis InBody 230 (Biospace, Korea). The foot screening included the assessment of foot posture index, which evaluates the degree of pronated, supinated and neutral position of the foot, gait speed and the last part of the procedure consisted of a short questionnaire, providing the information about the type of housing, age, and the usage of orthotics. Results: A low correlation between body composition and some of the foot posture index criteria was observed. The mean foot posture index score in athletes with ID was observed to be slightly pronated, as also described in the general population, with no statistically significant difference between female and male athletes. The gender differences were observed only in body composition. Conclusions: The high body weight and body fat percentage observed in this study highlight the need for healthy lifestyle education in athletes with ID.
\end{abstract}

Key words: foot posture index, intellectual disability, body composition, gait speed, sport

\section{Introduction}

Foot abnormalities and deformities can significantly affect the gait and others related daily activities. Compared to general population, gait capacities are affected in persons with intellectual disabilities (ID) [1] and a higher prevalence of podiatric conditions and deformities was observed among persons with ID in previous studies [2]-[4]. For this reason, Special Olympics, a sport organization for people with ID, introduced the Fit Feet program focused on podiatric screening of intellectually disabled athletes to their Healthy Athlete program [5]. The most common podiatric conditions found among the Special Olympics athletes include pes planus, abducted gait, pes cavus, hallux valgus and over-pronated gait [2], [3]. These podiatric conditions are mostly associated with ligamentous laxity and wearing a non-fitting footwear [3].
Foot posture index evaluates the foot by six criteria: talar head palpation, supra and infra malleolar curvature, calcaneal frontal plane position, prominence in the region of the talonavicular joint, congruence of the medial longitudinal arch and abduction/adduction of the forefoot on the rearfoot; quantifying the degree of pronated, supinated and neutral position of the foot [6]. The foot posture assessment is common in clinical practice for injury prevention and intervention. In population without ID, the participation in sports have been associated with a more pronated foot posture [7]. Additionally, flatter and more pronated foot posture has been observed in some of the previous studies in obese individuals [8], [9].

Excess weight and obesity is an important factor for the increased risk of mortality and morbidity from cardiovascular diseases, diabetes, cancers or musculoskeletal disorders [10] and obesity is more prevalent in people with ID compared to general population.

\footnotetext{
* Corresponding author: Marta Gimunová, Faculty of Sports Studies, Masaryk University Brno, Kamenice 5, 62500, Brno, Czech Republic. Phone: +420728367050, e-mail: gimunova@fsps.muni.cz

Received: July 4th, 2019

Accepted for publication: September 24th, 2019
} 
Within the population with ID, described risk factors of obesity are female gender, less severe intellectual disability, higher age, less physical activity, Down syndrome and the use of atypical antipsychotics [11]-[13]. Also in athletes participating in Special Olympics, who are regularly involved in physical activities, the levels of overweight and obesity are high, $24,7 \%$ and $32,1 \%$, respectively [14].

The purpose of this study was (i) to analyze the relationship between body composition and foot posture index, (ii) to analyze the effect of gender on the body composition and foot posture index, and finally, (iii) to analyze the factors affecting the body composition in athletes with ID participating in Special Olympics.

\section{Materials and methods}

Fit Feet clinical director and trained volunteers provided the screening of athletes with ID participating at Special Olympics National Table Tennis Tournament 2018 in the Czech Republic and at National Winter Games 2019, Czech Republic. Intelligence quotient of the athletes was below 75 points of IQ scale as it is in the Special Olympics regulation and indicated a moderate level of intellectual disability. The screening was performed in accordance with the ethical standards of the Helsinki Declaration. Informed consent for Healthy Athletes examinations is a part of the Czech Special Olympics Movement registration procedure and was provided by the athletes and their caregivers prior to the screening. Additionally, the participation in Special Olympics competitions is conditioned by participation in regular trainings during the year, providing at least 60 minutes of moderate physical activity per week.
131 athletes with intellectual disability participated in this study. 36 of them were table tennis players (7 females, 29 males), 66 cross country skiers (31 females, 35 males) and 29 downhill skiers (15 females, 14 males). The participants' mean age, body height, type of housing, a number of participants with Down syndrome in each group and the usage of orthopedic insoles in shown in Table 1.

The foot screening included the assessment of foot posture index, when the participants were standing still on both feet in a relaxed position, looking straight ahead. All observation was made by the same examiner. The six criteria: a talar head palpation (FPI-I), supra and infra malleolar curvature (FPI-II), calcaneal frontal plane position (FPI-III), prominence in the region of the talonavicular joint (FPI-IV), congruence of the medial longitudinal arch (FPI-V) and abduction/adduction of the forefoot on the rearfoot (FPIVI), were scored on a scale -2 to 2 , form highly supinated $(-2)$ to neutral $(0)$ and highly pronated $(+2)$ position for each foot [6].

Furthermore, gait speed was assessed when walking at a self-selected speed. Participants were instructed to walk down a 6-meter long pathway, consisting of a 1-meter long zone of acceleration, a 4-meter long testing pathway, where the gait speed was measured, and 1-meter long zone of deceleration. Three trials were performed and the result from the best trial was used for further analysis.

The body composition was assessed using the bioimpedance analysis InBody 230 (Biospace, Korea) to obtain the body mass $[\mathrm{kg}], \mathrm{kg}$ of muscle tissue, $\mathrm{kg}$ of fat tissue, total body water [kg], fat free mass [kg], body mass index (BMI), body fat percentage and waist-hip ratio. Body height was assessed using an anthropometer.

Finally, a short questionnaire was completed with a help of an examiner and coach or the caregiver when needed, providing the information about type of hous-

Table 1. Participants' characteristics

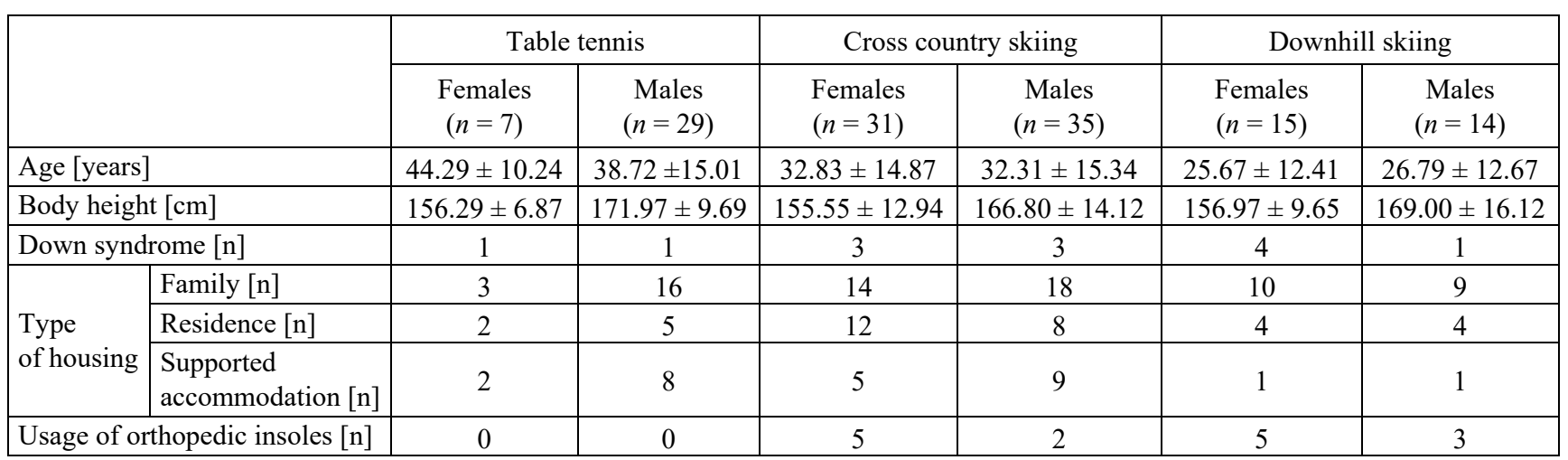


ing: family (living in family care, participating daily in school or job process), supported accommodation (living alone with mild support of social workers), residence (living in a residential home), age, and the usage of orthopedic insoles or shoes.

All the process took place in a separate, safety and quiet room. The athletes with ID were keen to participate as the procedure was a new phenomenon and an attraction for them.

\section{Statistical analysis}

Data were analyzed using Statistica 13.2. To analyze the relationship between the body composition and foot posture index, Spearman correlation was used. The effect of gender on body composition and foot posture index was calculated using a $t$-test. To analyze the effect of other variables (a type of housing, type of sport and gait speed) on the body composition in athletes with ID, ANOVA and consequent post hoc Tukey HSD test were performed. Alpha was set on 0.05 .

\section{Results}

The participants' mean gait speed, foot posture index and body composition characteristics are shown in Table 2.

\section{Correlation between the body composition and foot posture index}

FPI-I, a talar head palpation, was found to positively correlate with age ( $r=0.22$ and $r=0.19$ for the right and left foot, respectively). For FPI-II, supra and infra malleolar curvature, a positive correlation was found with body height $(r=0.22$ and $r=0.25$ for the right and left foot, respectively), fat-free mass ( $r=0.20$ and $r=0.19$ for the right and left foot, respectively) and muscle tissue ( $r=0.18$ for the right foot). Calcaneal frontal plane position (FPI-III) was observed to negatively correlate with body height $(r=-0.22$ and $r=-0.25$ for the right and left foot, respectively), muscle tissue ( $r=-0.18$ for both feet) and body weight ( $r=-0,19$ for the left foot). No correlation was found for the prominence in the region of the talonavicular joint (FPI-IV). The congruence of the medial longitudinal arch (FPI-V) was found to negatively correlate with age $(r=-0.35$ and $r=-0.36$ for the right and left foot, respectively) and fat tissue $(r=-0.19$ and $r=-0.18$ for the right and left foot, respectively). The abduction/adduction of the forefoot on the rearfoot (FPI-VI) was found to negatively correlate with the age $(r=-0.22)$, body height $(r=-0.22)$, body weight $(r=-0.18)$, muscle tissue $(r=-0.19)$ and total body water $(r=-0.17)$ for the left foot. FPI score was observed to negatively correlate with age $(r=-0.20$ and $r=-0.23$ for the right and left foot, respectively).

Table 2. Participants' gait speed, foot posture index and body composition characteristics

\begin{tabular}{|c|c|c|c|c|c|c|c|}
\hline & & \multicolumn{2}{|c|}{ Table tennis } & \multicolumn{2}{|c|}{ Cross country skiing } & \multicolumn{2}{|c|}{ Downhill skiing } \\
\hline & & $\begin{array}{c}\text { Females } \\
(n=7)\end{array}$ & $\begin{array}{l}\text { Males } \\
(n=29)\end{array}$ & $\begin{array}{l}\text { Females } \\
(n=31)\end{array}$ & $\begin{array}{l}\text { Males } \\
(n=35)\end{array}$ & $\begin{array}{l}\text { Females } \\
(n=15)\end{array}$ & $\begin{array}{c}\text { Males } \\
(n=14)\end{array}$ \\
\hline \multicolumn{2}{|c|}{ Gait speed $[\mathrm{m} / \mathrm{s}]$} & $0.74 \pm 0.16$ & $0.86 \pm 0.14$ & $0.85 \pm 0.14$ & $0.77 \pm 0.19$ & $0.84 \pm 0.14$ & $0.81 \pm 0.19$ \\
\hline \multirow{8}{*}{$\begin{array}{l}\text { Foot } \\
\text { posture } \\
\text { index }\end{array}$} & FPI-I & $0.43 \pm 0.53$ & $0.38 \pm 0.56$ & $0.00 \pm 0.00$ & $0.00 \pm 0.00$ & $0.20 \pm 0.41$ & $0.07 \pm 0.27$ \\
\hline & FPI-II & $0.00 \pm 0.82$ & $0.17 \pm 0.71$ & $0 \pm 0.26$ & $-0.03 \pm 0.17$ & $-0.20 \pm 0.41$ & $0.00 \pm 0.00$ \\
\hline & FPI-III & $0.14 \pm 0.69$ & $0.24 \pm 1.06$ & $0.06 \pm 0.57$ & $0.00 \pm 0.69$ & $0.33 \pm 1.05$ & $0.36 \pm 0.74$ \\
\hline & FPI-IV & $0.57 \pm 1.13$ & $0.55 \pm 0.95$ & $0.48 \pm 0.68$ & $0.60 \pm 0.69$ & $0.73 \pm 0.70$ & $0.86 \pm 0.53$ \\
\hline & FPI-V & $0.00 \pm 0.58$ & $0.52 \pm 0.95$ & $0.71 \pm 1.04$ & $0.89 \pm 0.96$ & $0.93 \pm 1.10$ & $1.07 \pm 1.07$ \\
\hline & FPI-VI & $0.00 \pm 1.63$ & $0.69 \pm 1.23$ & $1.03 \pm 1.05$ & $0.80 \pm 1.05$ & $0.87 \pm 1.25$ & $1.00 \pm 1.04$ \\
\hline & FPI score right & $1.00 \pm 3.83$ & $2.59 \pm 3.32$ & $2.26 \pm 2.61$ & $2.17 \pm 2.80$ & $2.93 \pm 3.61$ & $3.43 \pm 2.77$ \\
\hline & FPI score left & $0.71 \pm 1.80$ & $2.07 \pm 2.85$ & $2.26 \pm 2.61$ & $2.29 \pm 2.84$ & $2.87 \pm 3.64$ & $3.36 \pm 3.00$ \\
\hline \multirow{8}{*}{$\begin{array}{l}\text { Body } \\
\text { composition }\end{array}$} & Body weight $[\mathrm{kg}]$ & $67.84 \pm 14.28$ & $79.72 \pm 18.41$ & $62.87 \pm 20.00$ & $68.10 \pm 22.79$ & $66.66 \pm 13.98$ & $71.40 \pm 20.83$ \\
\hline & \begin{tabular}{|l|} 
Muscle tissue $[\mathrm{kg}]$ \\
\end{tabular} & $23.41 \pm 3.56$ & $32.66 \pm 5.84$ & $21.74 \pm 5.63$ & $28.63 \pm 8.30$ & $21.91 \pm 4.02$ & $29.21 \pm 7.81$ \\
\hline & \begin{tabular}{|l|} 
Fat tissue $[\mathrm{kg}]$ \\
\end{tabular} & $25.03 \pm 11.06$ & $21.66 \pm 10.62$ & $22.85 \pm 11.69$ & $16.46 \pm 11.34$ & $26.04 \pm 8.75$ & $18.94 \pm 10.65$ \\
\hline & Total body water $[\mathrm{kg}]$ & $31.49 \pm 4.36$ & $42.65 \pm 7.10$ & $29.36 \pm 6.92$ & $37.91 \pm 10.13$ & $29.79 \pm 4.88$ & $38.54 \pm 9.64$ \\
\hline & Fat free mass [kg] & $42.81 \pm 5.93$ & $58.07 \pm 9.75$ & $42.00 \pm 8.08$ & $55.83 \pm 10.95$ & $44.01 \pm 4.13$ & $58.12 \pm 8.07$ \\
\hline & Body mass index & $27.93 \pm 6.32$ & $26.81 \pm 5.17$ & $25.57 \pm 6.83$ & $23.93 \pm 5.66$ & $26.97 \pm 4.63$ & $24.54 \pm 4.86$ \\
\hline & Body fat percentage [\%] & $35.40 \pm 10.81$ & $25.88 \pm 8.10$ & $34.24 \pm 8.35$ & $22.42 \pm 9.29$ & $38.21 \pm 7.29$ & $25.08 \pm 8.94$ \\
\hline & Waist-hip ratio & $0.89 \pm 0.07$ & $0.91 \pm 0.09$ & $0.90 \pm 0.11$ & $0.89 \pm 0.07$ & $0.97 \pm 0.08$ & $0.89 \pm 0.05$ \\
\hline
\end{tabular}


The effect of gender on body composition and foot posture index

Statistically significant differences in analyzed variables between male and female athletes were found in body height $(p=0.000)$, body weight $(p=0.019)$, muscle tissue $(p=0.000)$, fat tissue $(p=0.009)$, total body water $(p=0.000)$, fat free mass $(p=0.000)$ and percentage of body fat $(p=0.000)$. The means for females and males and the p-value for variables, in which a statistically significant gender difference was observed, are shown in Table 3. No statistically significant difference in FPI variables between male and female athletes with ID was found.

Table 3. Gender differences of athletes with ID in body composition

\begin{tabular}{|l|c|c|c|}
\hline & $\begin{array}{c}\text { Females } \\
(n=53)\end{array}$ & $\begin{array}{c}\text { Males } \\
(n=78)\end{array}$ & $p$ \\
\hline Body height $[\mathrm{cm}]$ & 156.047 & 169.115 & 0.000 \\
\hline Body weight $[\mathrm{kg}]$ & 64.602 & 73.015 & 0.019 \\
\hline Muscle tissue $[\mathrm{kg}]$ & 22.009 & 30.229 & 0.000 \\
\hline Fat tissue $[\mathrm{kg}]$ & 24.042 & 18.837 & 0.009 \\
\hline Total body water $[\mathrm{kg}]$ & 29.764 & 39.785 & 0.000 \\
\hline Fat free mass $[\mathrm{kg}]$ & 42.558 & 57.126 & 0.000 \\
\hline Percentage of body fat $[\%]$ & 35.515 & 24.183 & 0.000 \\
\hline
\end{tabular}

\section{Factors affecting the body composition}

Statistically significant differences between athletes living with family, at supported accommodation or in residence were observed in age $(p=0.000)$, body height ( $p=0.003)$, body weight $(p=0.006)$, muscle tissue $(p=0.001)$ and total body water $(p=0.001)$. Most of the statistically significant differences were observed between participants living in residence and family or supported accommodation (Table 4).

Table 4. The effect of different types of housing on body composition in athletes with ID

\begin{tabular}{|l|c|c|c|c|}
\hline & $\begin{array}{c}\text { Family }^{(1)} \\
(n=70)\end{array}$ & $\begin{array}{c}\text { Supported } \\
\text { accommodation }^{(2)} \\
(n=26)\end{array}$ & $\begin{array}{c}\text { Residence }^{(3)}(n=35) \\
{ }^{*}\end{array}$ & $p$ \\
\hline Age [years] & $32.04^{*(2)}$ & $46.04^{*(1,3)}$ & $25.77^{*(2)}$ & 0.000 \\
\hline $\begin{array}{l}\text { Body } \\
\text { height [cm] }\end{array}$ & $165.00^{*(3)}$ & $169.04^{*(3)}$ & $157.62^{*(1,2)}$ & 0.003 \\
\hline $\begin{array}{l}\text { Body } \\
\text { weight [kg] }\end{array}$ & $72.45^{*(3)}$ & $\left.74.42^{*(3}\right)$ & $60.36^{*(1,2)}$ & 0.006 \\
\hline $\begin{array}{l}\text { Muscle } \\
\text { tissue [kg] }\end{array}$ & $27.77^{*(3)}$ & $29.90^{*(3)}$ & $22.94^{*(1,2)}$ & 0.001 \\
\hline $\begin{array}{l}\text { Total body } \\
\text { water [kg] }\end{array}$ & $36.83^{*(3)}$ & $39.37^{*(3)}$ & $30.83^{*(1,2)}$ & 0.001 \\
\hline $\begin{array}{l}\text { Fat free } \\
\text { mass [\%] }\end{array}$ & 52.41 & 53.54 & 45.97 & 0.040 \\
\hline
\end{tabular}

* Differences between different types of housing $(p<0.05)$, post hoc Tukey HSD test.
Additionally, statistically significant differences between table tennis players, cross country skiers and downhill skiers were found in body weight $(p=0.018)$, age $(p=0.001)$, body height $(p=0.032)$, muscle tissue $(p=0.001)$, total body water $(p=0.002)$ and fat free mass $(p=0.045)$. Most of the statistically significant differences were observed between table tennis players and cross country skiers (Table 5).

Table 5. The effect of different sports on body composition in athletes with ID

\begin{tabular}{|l|c|c|c|c|}
\hline & $\begin{array}{c}\text { Table tennis }^{(1)} \\
(n=36)\end{array}$ & $\begin{array}{c}\text { Cross country } \\
\text { skiing }^{(2)} \\
(n=66)\end{array}$ & $\begin{array}{c}\text { Downhill } \\
\text { skiing }^{(3)} \\
(n=29)\end{array}$ & $p$ \\
\hline Age [years] & $39.81^{*(2,3)}$ & $32.56^{*(1)}$ & $26.20^{*(1)}$ & 0.001 \\
\hline $\begin{array}{l}\text { Body } \\
\text { height [cm] }\end{array}$ & $168.92^{*(2)}$ & $161.52^{*(1)}$ & 162.78 & 0.032 \\
\hline $\begin{array}{l}\text { Body } \\
\text { weight }[\mathrm{kg}]\end{array}$ & $77.41^{*(2)}$ & $65.65^{*(1)}$ & 68.95 & 0.018 \\
\hline $\begin{array}{l}\text { Muscle } \\
\text { tissue }[\mathrm{kg}]\end{array}$ & $30.86^{*(2,3)}$ & $25.39^{*(1)}$ & $25.43^{*(1)}$ & 0.001 \\
\hline $\begin{array}{l}\text { Total body } \\
\text { water [kg] }\end{array}$ & $40.48^{*(2,3)}$ & $33.89^{*(1)}$ & $34.01^{*(1)}$ & 0.002 \\
\hline $\begin{array}{l}\text { Fat free } \\
\text { mass [kg] }\end{array}$ & $55.10^{*(2)}$ & $49.04^{*(1)}$ & 51.07 & 0.045 \\
\hline
\end{tabular}

* Differences between different sports $(p<0.05)$, post hoc Tukey HSD test.

The gait speed was not observed to significantly affect the body composition or foot posture criteria.

\section{Discussion}

The purpose of this study was to analyze the relationship between the body composition and foot posture index, to analyze the effect of gender on the body composition and foot posture index, and to analyze the factors affecting the body composition in athletes with ID participating in Special Olympics, as in athletes with ID the foot deformities, abnormal postural patterns and overweight and obesity was observed to be more common than in the general population [2]-[4], [11]-[13], [15].

In general population the foot posture index was found not to be influenced by gender or BMI [16]. However, in previous studies, the age effect on the foot posture index score was described. In both, older adults and young children, more pronated foot posture indexes were observed [16], [17]. Additionally, a neutral or slightly pronated $(+4)$ foot posture index is normal position at rest in healthy adult population [16]. 
Similarly, in athletes with ID, the mean FPI score was slightly pronated and no statistically significant difference in foot posture index between females and males were found. In contrast to the general population, the age was found to negatively correlate with foot posture index criteria in athletes with ID. This difference might be caused by the age range in our athletes, where the elderly population was missing, and therefore, the results showed more pronated foot posture only in younger athletes.

Statistically significant correlations of foot posture index criteria and body composition were ranged in a low correlation. Supra and infra malleolar curvature positively correlated with body height, fat free mass and muscle tissue suggesting a more pronated posture in athletes with higher body height, fat free mass and muscle tissue. Analogous observation was described in a study by Rabiatti Aurichio et al. [9] on elderly people and explained by a greater amount of fat in the lower limbs and edema formation in the obese people in this foot region, which may be interpreted as a foot supination [9]. Calcaneal frontal plane position was observed to negatively correlate with body height, muscle tissue and body weight. Pronated posture of calcaneus is often associated with a flat foot, pes planus, which may lead to increased fatigue and pain during physical activities and, therefore, to a lower level of muscle tissue compared to neutral and supinated calcaneus position [18], [19]. The congruence of the medial longitudinal arch was found to negatively correlate with fat tissue in athletes with ID. In contrast to this finding, in previous studies on general population, the BMI was not observed to differ in population with or without flat feet [19], or a flatter and more pronated foot posture has been reported in previous studies in obese individuals [8], [9]. The abduction/adduction of the forefoot on the rearfoot was found to negatively correlate with the body height, body weight, muscle tissue and total body water for the left foot. Similar observation, a difference between left and right foot in FPI-VI was observed in previous study in association to recent physical activity [20].

As factors affecting the body composition recognized were gender, type of sport and type of housing. A significantly higher percentage of body fat was observed in female athletes, compared to males. This finding is in accordance with previous studies, where the female sex was reported to be a risk factor for obesity in both general population and in population with ID [11]-[13], [21]. Statistically significant differences between table tennis players, cross country skiers and downhill skiers were found in body weight, age, body height, muscle tissue, total body water and fat free mass and were predominantly caused by the different proportion of female and male athletes in each group and different sports' needs. Furthermore, age, body height, body weight, muscle tissue, total body water and fat free mass were observed to significantly differ with the type of housing. Body weight was the lowest in athletes living in the residence, probably associated with their younger age and smaller body height. Additionally, in the residence meals are prepared under a supervision and also in previous studies a smaller proportion of overweight and obese individuals with ID was observed in this type of housing [22], [23].

The mean gait speed in athletes with ID observed in this study was $0.82 \pm 0.16 \mathrm{~m} / \mathrm{s}$. In the general population the cut point of $1.0 \mathrm{~m} / \mathrm{s}$ was suggested as a predictor for health-related events, disability, falls and cognitive impairment [24]-[26]. However, the gait speed in adults with ID was observed to be slower than in the general population as the balance and gait capacities are affected in persons with ID [27], [28].

The unique constrains in athletes with ID and the unknown proportion of different syndromes associated with both intellectual disabilities and foot and gait abnormalities, such as Fragile X syndrome, or Smith Magenis syndrome, constitutes the limitation of this study. Future studies focused on gait biomechanics of athletes with ID will provide a more detailed insight into the specific foot conditions, body composition, age and sports performance relationship and the possibilities for foot care and healthy lifestyle education in the population with ID.

\section{Conclusions}

A low correlation between body composition and foot posture index criteria was observed. The mean foot posture index score in athletes with ID was observed to be slightly pronated, as also described in the general population, with no statistically significant difference between female and male athletes. The gender differences were observed only in body composition. Other factors affecting the body composition found in this study were the type of sport and type of housing. The high body weight and body fat percentage observed in this study highlight the need for healthy lifestyle education in athletes with ID.

\section{Acknowledgement}

This study is a part of the project SOI - Golisano foundation Y3 18 600-28. 


\section{References}

[1] EnkelaAr L., SMulders E., VAN Schrojenstein Lantman-DE VAlK H., GeurTs A.C.H., Weerdesteyn V., A review of balance and gait capacities in relation to falls in persons with intellectual disability, Research in Developmental Disabilities, 2012, 33, 291-306.

[2] GimunovÁ M., VÁlkovÁ H., HRNČIŘíKOvÁ I., ZvONAŘ M., Prevalence of podiatric conditions in Special Olympics athletes: the Czech Republic winter games Fit Feet screening, 8th International Scientific Conference on Kinesiology, Opatija, Croatia, D. Milanović, G. Sporiš, S. Šalaj and D. Škegro (Eds.), Faculty of Kinesiology, University of Zagreb, Zagreb, Croatia, 2017, 32-35.

[3] Jenkins D.W., Cooper K., O'Connor R., Watanabe L., WiLls C., Prevalence of podiatric conditions seen in Special Olympics athletes: Structural, biomechanical and dermatological findings, The Foot, 2011, 21, 15-25.

[4] Jenkins D.W., Cooper K., Heigh E.G., Prevalence of podiatric conditions seen in Special Olympics athletes: A comparison of USA data to an international population, The Foot, 2015, 25, 5-11.

[5] Special Olympics Fit Feet Resources, 2019, Version January 2019, Special Olympics, Inc., https://resources.specialolympics.org/ Taxonomy/Health/Fit_Feet_INT.aspx

[6] Redmond A., The Foot Posture Index: User guide and manual, 2005. Retrieved September 29, 2014, from: http:// www.leeds.ac.uk/medicine/FASTER/z/pdf/FPI-manual-formatted -August-2005v2.pdf

[7] KuO Y.L., LiU Y.S.L., The foot posture index between elite athletic and sedentary college students, Kinesiology, 2017, 49, 202-207.

[8] Butterworth P.A., Urquhart D.M., Landorf K.B., Wluka A.E., Cicuttini F., Menz H.B., Foot posture, range of motion and plantar pressure characteristics in obese and non-obese individuals, Gait and Posture, 2015, 41, 465-469.

[9] Rabiatti Aurichio T., Rebelatto J.R., Paiva de Castro A., The relationship between the body mass index (BMI) and foot posture in elderly people, Archives of Gerontology and Geriatrics, 2011, 52, e89-e92.

[10] Finucane M.M., Stevens G., Cowan M., Danaei G., Lin J.K., PACIOREK C.J., SingH G.M. et al., National, regional, and global trends in body-mass index since 1980: systematic analysis of health examination surveys and epidemiological studies with 960 country-years and 9.1 million participants, Lancet, 2011, 377, 557-567.

[11] EMERSON E., Underweight, obesity and exercise among adults with intellectual disabilities in supported accommodation in Northern England, Journal of Intellectual Disability Research, 2005, 49, 134-143.

[12] De Winter C.F., BastiaAnse L.P., HilgenKamp T.I.M., Evenhuis H.M., ECHTELD M.A., Overweight and obesity in older people with intellectual disability, Research in Developmental Disabilities, 2012, 33, 398-405.

[13] HSien K., Rimmer J.H., Heller T., Obesity and ID, Journal of Intellectual Disability Research, 2014, 58, 851-863.
[14] Temple V.A., Foley J.T., Lloyd M., BMI of adults with intellectual disability, Journal of Intellectual Disability Research, 2014, 58, 277-284.

[15] Bibrowicz K., Szurmik T., Wodarski P., Michnik R., Myśliwiec A., Barszcz J., Mikolajowski G., Mitas A., Quality of body posture and postural stability in people with intellectual disability playing volleyball, Acta of Bioeng. Biomech., 2019, 21, 23-30.

[16] Redmond A.C., Crane Y.Z., Menz H.B., Normative values for the foot posture index, Journal of Foot and Ankle Research, $2008,1$.

[17] Scott G., Menz H.B., Newcombe L., Age-related differences in foot structure and function, Gait and Posture, 2007, 26, 68-75.

[18] LevitovÁ A., HošKovÁ B., Zdravotně-kompenzačni cvičení, Grada publishing, Prague, Czech Republic, 2015.

[19] Shibuya N., Kitterman R.T., LaFontaine J., Jupiter D.C., Demographic, Physical, and Radiographic Factors Associated with Functional Flatfoot Deformity, The Journal of Foot and Ankle Surgery, 2014, 53, 168-172.

[20] COWLEY E., MARSDEN J., The effects of prolonged running on foot posture: a repeated measures study of half marathon runners using the foot posture index and navicular height, Journal of Foot and Ankle Research, 2013, 6.

[21] Lovejoy J.C., The Influence of Sex Hormones on Obesity across the Female Life Span, Journal of Women's Health, 1998, 7, 1247-1256.

[22] Jankowicz-SZYManska A., Mikolajczyk E., WoJTANOWSKi W., The effect of the degree of disability on nutritional status and flat feet in adolescents with Down syndrome, Research in Developmental Disabilities, 2013, 34, 3686-3690.

[23] Mikulovic J., Vanhelst J., Salleron J., Marcellini A., COMPTE R., FARDY P.S. et al., Overweight in intellectuallydisabled population: Physical, behavioral and psychological characteristics, Research in Developmental Disabilities, 2014, 35, 153-161.

[24] Cesari M., Kritchevsky S.B., Penninx B.W., Nicklas B.J., Simonsick E.M., Newman A.B. et al., Prognostic value of usual gait speed in well-functioning older people, Journal of the American Geriatrics Society, 2005, 53, 1675-1680.

[25] Studenski S., Perera S., Patel K., Rosano C., Faulkner K., InZITARI M. et al., Gait Speed and Survival in Older Adults, JAMA, 2011, 305, 50-58.

[26] van Kan A.G., Rolland Y., Andrieu S., Bauer J., BEAUCHET O., BONNEFOY M. et al., Gait speed at usual pace as a predictor of adverse outcomes in community-dwelling older people, Journal of Nutrition Health and Aging, 2009, 13, 881-889.

[27] EnKelaar L., Smulders E., Van Schrojenstein Lantman-DE VAlk H., Weerdesteyn V., Geurts A.C.H., Clinical measures are feasible and sensitive to assess balance and gait capacities in older persons with mild to moderate Intellectual Disabilities, Research in Developmental Disabilities, 2012, 34, 276-285.

[28] HAYNes C.A., LOCKHART T.E., Evaluation of gait and slip parameters for adults with intellectual disability, Journal of Biomechanics, 2012, 45, 2337-2341. 